\title{
SEQUÊNCIA DIDÁTICA DE GÊNEROS DOS QUADRINHOS PARA O ENSINO DE LÍNGUA INGLESA - POSSIBILIDADES E DESAFIOS
}

\author{
Didactic Sequence of Comics Genres for English Language Teaching - \\ Possibilities and Challenges
}

\author{
Claudia Lopes PONTARA \\ clpontara@bol.com.br \\ Doutoranda, Universidade Estadual de Londrina
}

Vera Lúcia Lopes CRISTÕVÃO

Universidade Estadual de Londrina

cristova@uel.br

\begin{abstract}
RESUMO: Este artigo, parte de uma pesquisa de mestrado ${ }^{1}$, visa a descrever e analisar a organização de uma SD com base nos elementos ensináveis de três gêneros dos quadrinhos que embasaram sua elaboração - comics, comic strips, political cartoon, com foco nas possibilidades e desafios que permeiam esse processo. $\mathrm{O}$ arcabouço teórico-metodológico norteador deste estudo fundamenta-se no Interacionismo Sociodiscursivo, Sequência Didática e Capacidades de Linguagem, Transposição Didática, bem como nos estudos voltados aos gêneros dos quadrinhos. Os resultados demonstram que, um material organizado a partir das concepções teóricas adotadas, pode vir a promover um ensino mais significativo e sólido, tendo em vista a possibilidade de envolver toda a complexidade que constitui tais gêneros. Por outro lado, os desafios se apresentam quando se leva em consideração as condições objetivas e subjetivas de trabalho do professor que almeja uma transformação em sua prática em sala de aula. PALAVRAS-CHAVE: Gêneros Dos Quadrinhos; Elementos Ensináveis; Sequência Didática; Língua Inglesa.
\end{abstract}

\begin{abstract}
This article, part of a master's research, aims to describe and analyze the organization of a DS based on the teachable elements of three comics genres that supported its elaboration - comics, comic strips and political cartoon, with a focus on the possibilities and challenges that permeate this process. The theoretical-methodological
\end{abstract}

\footnotetext{
${ }^{1}$ A referida pesquisa, intitulada "Gêneros textuais e sequência didática propiciando um ensino significativo de análise linguística e expressão escrita em língua inglesa" foi defendida no ano de 2015, no Mestrado de Estudos da Linguagem da Universidade Estadual de Londrina (UEL).
} 
framework guiding this study is based on Sociodiscursive Interactionism, Didactic Sequence and Language Capacities, Didactic Transposition, as well as studies focused on the genres of comics. The results demonstrate that a material based on the theoretical conceptions adopted in this study can promote a more meaningful and solid teaching, considering the possibility of involving all the complexity that constitutes such genres. On the other hand, the challenges arise when taking into account the objective and subjective conditions of work of the teacher who aims to transform his/her practice in the classroom. KEYWORDS: Comics Genres; Teachable Elements; Didactic Sequence; English Language.

\section{INTRODUÇÃO}

A elaboração de uma Sequência Didática - SD com base nos gêneros dos quadrinhos surge como fruto das experiências profissionais dos professores elaboradores ${ }^{2}$, os quais, na maioria das vezes, encontram os referidos gêneros, nos livros didáticos, apenas como pretexto para o ensino de vocabulário e/ou de gramática, para enfocar um determinado tema, ou ainda, somente para um momento de leitura como descontração. Diante desse contexto, viram-se motivados pela necessidade de organizar um trabalho que possibilitasse um processo de ensino e aprendizagem voltado, de forma mais efetiva, para a compreensão da relação que ocorre entre a linguagem verbal e não verbal, além da compreensão dos implícitos que inserem o leitor em uma leitura prazerosa e, ao mesmo tempo, instigante e viabilizadora de possibilidades de ação social, como é o caso dos gêneros dos quadrinhos.

Dessa forma, para além de tratar tais gêneros como textos motivacionais para o ensino de língua inglesa ou como pretextos para ensino de gramática, a SD elaborada visou possibilitar um estudo sistematicamente organizado de língua inglesa com base em três gêneros pertencentes aos gêneros dos quadrinhos: comics, comic strips e political cartoon, visando a um agir social que engajasse os alunos.

\footnotetext{
${ }^{2}$ A SD em análise foi elaborada em um processo que teve início em 2009, organizado pela Coordenação Geral do Centro de Línguas Estrangeiras do Estado do Paraná (CELEM). Um grupo de professores de Língua Inglesa, Espanhola e Francesa da Rede Estadual de Ensino foi selecionado para elaborar materiais das referidas línguas, sob a orientação de professoras consultoras pertencentes a Instituições de Ensino Superior dos estados de São Paulo, Rio Grande do Sul e Paraná. As Sequências Didáticas foram produzidas durante os anos de 2010, 2011 e 2012.
} 
Para este artigo, descrevemos e analisamos a organização da SD, com base nos elementos ensináveis dos gêneros enfocados. O texto está organizado em cinco seções, incluindo a Introdução. A Seção dois trata dos aportes teóricos norteadores desse estudo, a saber: Interacionismo Sociodiscursivo - ISD (BRONCKART, 2006, 2012), Sequência Didática e Capacidades de Linguagem (DOLZ; NOVERRAZ; SCHNEUWLY, 2010; CRISTOVÃO, 2010; CRISTOVÃO; STUTZ,2011; CRISTOVÃO;2013), Transposição Didática (CHEVALLARD, 1985, 1989; MACHADO E CRISTOVÃO, 2006; STUTZ, 2012; NASCIMENTO, 2010), bem como os estudos voltados aos gêneros dos quadrinhos (MATTAR, 2010, McCLOUD, 2007; MENDONÇA, 2010; CATTO e HENDGES,2010; CRISTOVÃO, DURÃO e NASCIMENTO, 2007; SANTOS, 2002; LEAL, 2011). A Seção três apresenta a metodologia empregada, seguida da Seção quatro onde são realizadas as análises. Finalizamos com as Considerações Finais e Referências.

\section{APORTES TEÓRICOS DE BASE}

\section{Interacionismo sociodiscursivo e contribuições para o processo de ensino e aprendi- zagem de línguas}

Adotamos o ISD como o suporte teórico de base que sustenta nossos estudos, ao partirmos do entendimento de que a língua é um fenômeno social e que, assim o sendo, a interação social assume papel indispensável na constituição da linguagem e vice-versa. E, apesar de ser esse um quadro teórico relativamente recente e em construção, acreditamos que suas discussões têm trazido, e podem trazer ainda mais, grandes contribuições para o processo de ensino e aprendizagem de línguas com base em gêneros.

Sem dúvida, realizar a transposição didática dos modelos teóricos e das pesquisas empíricas (BRONCKART, 2006) tem sido um desafio para os professores ao se depararem com documentos oficiais que sinalizam, por exemplo, para um ensino com base em gêneros. Nesse sentido, de acordo com Cristovão (2010), o procedimento SD constituise na proposta do ISD para esse ensino com base em gêneros, confirmando a afirmação de que nossa escolha por tal suporte teórico se deu tendo em vista o nosso anseio por um processo de ensino e aprendizagem de línguas mais efetivo e significativo.

Reportamos à questão da transposição didática ${ }^{3}$, a qual, a partir do arcabouço

\footnotetext{
${ }^{3} \mathrm{O}$ termo "transposição didática" não é recente. Foi criado pelo sociólogo francês Michel Verret, em 1975, tendo sido aprofundado por Yves Chevallard, matemático e educador francês, segundo o qual: "A transição do conhecimento considerado como uma ferramenta para ser colocada em uso, para o conhecimento como algo a ser ensinado e aprendido, é precisamente o que eu tenho
} 
teórico-metodológico assumido por nós, demanda, inicialmente, dentre outras coisas, ter clareza sobre o que os termos linguagem, texto e gênero representam, ao se propor um trabalho com gêneros na perspectiva do ISD. Contudo, o conhecimento/entendimento da teoria por si só não garante que se estabeleça um processo de ensino e aprendizagem com base em gêneros ( seja a partir de qualquer perspectiva teórica ${ }^{4}$ ), visto que tais conhecimentos precisam ser transpostos para o contexto da sala de aula, ou com outras palavras, é preciso haver a transformação/adaptação dos conhecimentos científicos em conhecimentos a serem ensinados. Em nosso caso, a transposição didática dos conhecimentos relacionados aos gêneros comics, comic strip, political cartoon envolvendo o tema do voluntariado precisou acontecer. Ou seja, esses conhecimentos precisaram ser didatizados, passar por sistematizações, adequações, mudanças para serem trazidos para a sala de aula.

Realizar a transposição didática, portanto, requer ações que, de acordo com Machado e Cristovão (2006), constituem-se em três níveis básicos de transformações: I) Conhecimentos científicos; II) Conhecimentos a serem ensinados; III) Conhecimentos efetivamente ensinados e aprendidos; os quais estão inseridos, de acordo com Chevallard (1985) no nível externo e interno de transposição. Quanto aos níveis interno e externo, Stutz (2012) esclarece que, ao transformarmos um objeto a saber em um objeto a ensinar, estaremos atuando no nível da transposição didática externa. Ao passo que a interna corresponde à transformação do objeto a ensinar ao objeto ensinado.

A respeito da complexidade do processo de transposição didática, Machado e Cristovão (2006) discorrem sobre a compartimentalização dos conhecimentos, o que motivou os pesquisadores francófonos a buscarem alternativas que os auxiliassem a superá-la, dando origem, assim, ao Modelo Didático do Gênero - MDG. Cristovão e Nascimento (2011), ao discorrerem sobre o MDG afirmam ser esta uma fonte preciosa de informações, constituindo-se em um material essencial para que o professor possa, a partir dele, fazer as alterações/escolhas necessárias para a transposição didática adequada à realidade em que atua.

Contudo, a elaboração de um MDG exige, inicialmente, que se faça a opção pelo gênero a ser didatizado. Quanto a essa escolha e quanto à escolha do tema para o desenvolvimento com o gênero em sala de aula, Cristovão (2007), com base em

chamado de transposição didática do conhecimento"(CHEVALLARD, 1989, p. 6 - tradução nossa).

${ }^{4}$ Citamos, por exemplo, a perspectiva bakhtiniana, a sócio-retórica, a análise do discurso crítica, a sistêmico funcional, dentre outras. 
Dolz e Schneuwly (1998), apresenta quatro dimensões que devem ser consideradas: I) dimensão psicológica, observando motivações, afetividade, interesses dos alunos; II) dimensão cognitiva, estimando a complexidade do tema e o estatuto do conhecimento dos alunos; III) dimensão social, envolvendo a densidade social do tema, com vistas a desenvolver um projeto de classe e, IV) dimensão didática, explorando um tema que não seja excessivamente cotidiano e que comporte o apreensível.

Ainda nesse contexto de transposição didática externa, discorremos, a seguir, sobre a elaboração da SD para o ensino de línguas pautado nos gêneros.

Os autores genebrinos Dolz, Noverraz e Schneuwly (2010, p. 82) definem uma SD como "[...] um conjunto de atividades escolares organizadas, de maneira sistemática, em torno de um gênero textual oral ou escrito", cujo objetivo é ajudar o aluno a dominar um gênero textual, possibilitando-lhe escrever e/ou falar de uma maneira mais apropriada em uma situação de comunicação. Os pesquisadores complementam afirmando que "As sequências didáticas servem, portanto, para dar acesso aos alunos a práticas de linguagem novas ou dificilmente domináveis" (DOLZ; NOVERRAZ; SCHNEUWLY, 2010, p. 83). De acordo com o grupo de Genebra, a estrutura de base de uma SD se configura em etapas assim denominadas: a) apresentação da situação; b) produção inicial; c) módulos necessários, de acordo com as necessidades de aprendizagem de uma determinada turma de alunos e d) produção final.

No caso específico deste estudo, a elaboração da SD contemplou as etapas de elaboração de uma SD, conforme descrito anteriormente. Contudo, houve adaptações. O que se justifica, em parte, por tratar-se de uma SD para o ensino de língua estrangeira (inglês). Pensando nas possíveis adaptações a serem adotadas ao se elaborar uma SD para o contexto brasileiro de ensino de línguas, o Grupo de Pesquisa Linguagem e Educação apresenta uma possibilidade de reconfiguração, conforme demonstrado na Figura 1: 
Figura 1: A SD na simbologia do DNA
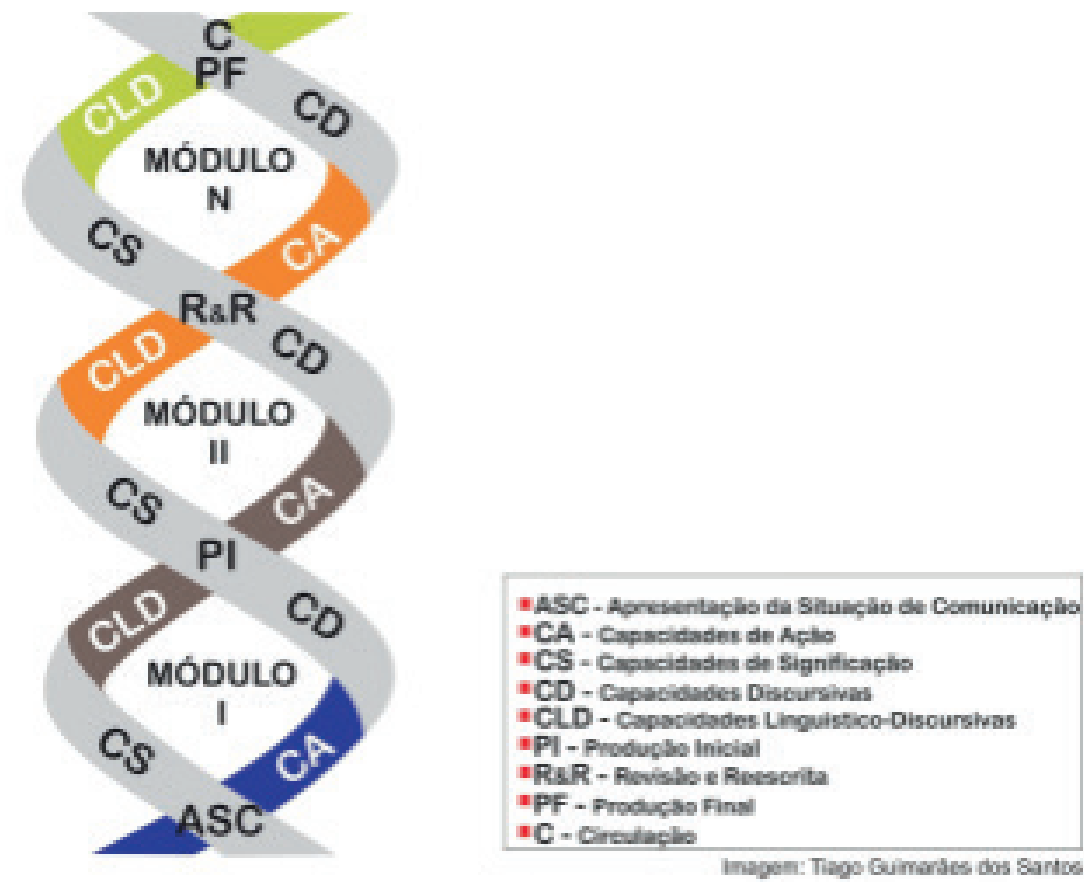

Fonte: Miquelante, Cristovão e Pontara (no prelo)

A proposta da simbologia do DNA para reconfigurar o esquema de elaboração de uma SD tem o objetivo de tornar mais visível toda a articulação existente entre as CL e as etapas da SD. Objetiva, ainda, marcar a expansão feita com relação às atividades de revisão e reescrita que ocorrem no decorrer de todos os módulos, entremeando-se a eles, caracterizando, fortemente, a escrita como processo e não como produto.

Deparamo-nos, comisso, com o foco das aulas de línguas, a saber, o desenvolvimento das Capacidades de Linguagem ${ }^{5}$ dos alunos, as quais se organizam em quatro grupos: Capacidades de Significação - CS, Capacidades de Ação - CA, Capacidades Discursivas CD, Capacidades Linguístico-discursivas - CLD, podendo ser mobilizadas mediante as

\footnotetext{
${ }^{5}$ Importa destacar que o Grupo Genebrino apresenta três capacidades de linguagem, quais sejam: Capacidades de Ação, Capacidades Discursivas e Capacidades Linguístico-discursivas. Como forma de expansão dos estudos realizados pelos pesquisadores de Genebra, o Grupo de Pesquisa Linguagem e Educação, sob a liderança da Professora Doutora Vera Lúcia Lopes Cristovão apresenta mais duas capacidades de linguagem, a saber: Capacidades de Significação (CRISTOVÃO E STUZ, 2011; CRISTOVÃO, 2013) e as Capacidades Multissemióticas (LENHARO, 2016). Contudo, as Capacidades Multissemióticas não foram inseridas neste estudo, visto ter sido realizado anteriormente à pesquisa de Lenharo.
} 
atividades propostas em uma SD.

Mencionadas as quatro capacidades de linguagem, é necessário frisar que elas não são e não podem ser vistas como estanques, como fases/etapas de uma aula em que se propõe um trabalho a partir de gêneros textuais. Ao contrário, elas são complementares, são combinadas em busca de significações para o que se lê, se escreve, ouve ou fala. Nesse sentido, Cristovão e Stutz (2011, p.23) argumentam que "Vale ressaltar que entendemos as capacidades como articuladas e atravessadas entre si colaborando para ser, estar, (inter) agir no mundo."

Com o objetivo de tornar claras as especificidades dos gêneros abordados na $\mathrm{SD}$, apresentamos uma breve explanação sobre cada um deles. Apesar dos três gêneros escolhidos serem muito similares em suas características, cada qual possui suas especificidades, conforme vemos a seguir.

\section{Os gêneros dos quadrinhos - características contextuais, discursivas e linguístico- -discursivas.}

O termo "gêneros dos quadrinhos" nos remete a uma diversidade de gêneros, dentre os quais podemos citar as histórias em quadrinhos, quadrinhos autorais, mangás, tiras, tiras seriadas, charges, cartoons, caricaturas etc. No caso específico da SD analisada, sua elaboração se deu com base nas tiras (comic strips), histórias em quadrinhos (comics) e charges (political cartoons).

Apesar de os gêneros enfocados apresentarem características visuais bem próximas, possuem especificidades, principalmente, quanto à função social e estrutura composicional. Entendemos que também são carregados de grande complexidade discursiva, demandando um estudo sistematizado, tanto por parte do produtor que se dispõe a produzir tais textos, quanto de quem irá ler e interagir com eles.

Sem ter a pretensão de trazer definições que desconsiderem todos os estudos específicos da arte dos quadrinhos, e, mais ainda, sem ter o intuito de reduzir os gêneros em estudo a definições que os categorizem em estruturas rígidas, apresentamos, a seguir, uma possibilidade de olhar para tais gêneros, de modo a torná-los mais compreensíveis, visando a uma prática pedagógica voltada para o trabalho com a língua inglesa com base nos gêneros comics, comic strips, political cartoon, uma vez que a proposta da SD envolve tanto a leitura quanto a produção de gêneros dos quadrinhos.

No Quadro 1 apresentamos algumas caracterizações acerca dos gêneros abordados na SD usada neste estudo, com base em autores da área. 
Quadro 1: Os gêneros enfocados na SD e suas caracterizações

\begin{tabular}{|c|c|}
\hline Histórias em quadrinhos & Comics \\
\hline $\begin{array}{l}\text { "O termo histórias em quadrinhos se refere a um } \\
\text { aspecto mais abrangente, ou seja, às histórias } \\
\text { narrativas que são contadas sequencialmente, } \\
\text { independente da quantidade de quadrinhos." } \\
\text { (MATTAR, 2010, p. 47). }\end{array}$ & $\begin{array}{l}\text { "Imagens pictóricas e outras justapostas em } \\
\text { sequência deliberada, destinados a transmitir } \\
\text { informações e/ou produzir uma resposta estética no } \\
\text { espectador." (MCCLOUD, 2007, p. 1). }\end{array}$ \\
\hline $\begin{array}{l}\text { "[...] história contada em quadros (vinhetas), ou } \\
\text { seja, é um sistema narrativo composto de dois } \\
\text { meios de expressão distintos, o desenho e o texto." } \\
\text { Seu veículo principal é o próprio quadrinho, criado } \\
\text { para transmitir uma mensagem. Ao juntar dois ou } \\
\text { mais quadros para contar uma história, obtém-se } \\
\text { uma sequência. É ela que sugere a ação da história." } \\
\text { (HOFFMANN; COSTA, 2009, p. 11). }\end{array}$ & \\
\hline Tirinhas & Comic Strips \\
\hline $\begin{array}{l}\text { "São culturalmente situadas, sendo que para } \\
\text { que suas funções de causar graça e de criticar } \\
\text { sejam percebidas, devem ser interpretadas dentro } \\
\text { dos contextos onde são publicadas." (CATTO, } \\
\text { HENDGES, 2010, p 197). } \\
\text { "Os quadrinhos curtos, popularmente publicados } \\
\text { em jornais dominicais são conhecidos como } \\
\text { "tirinhas", por seu formato horizontalmente } \\
\text { comprido." (PRESSER; SCHLÖGL, 2013, p.4). }\end{array}$ & $\begin{array}{l}\text { "[...] uma sequência de desenhos, tanto a cores } \\
\text { como preto e branco, referente a um incidente } \\
\text { cômico, uma história de aventura ou mistério, } \\
\text { etc., muitas vezes serializado, tendo, tipicamente, } \\
\text { diálogo em balões, e normalmente impresso em } \\
\text { uma tira horizontal em jornais diários e em um } \\
\text { bloco ininterrupto ou sequência mais longa de } \\
\text { tais tiras em jornais de domingo e em revistas em } \\
\text { quadrinhos." (COMIC STRIP. [S.1.: s.n., 19--]) }\end{array}$ \\
\hline Charge & Political cartoon \\
\hline $\begin{array}{l}\text { "Transmite informações que envolvem fatos e é, ao } \\
\text { mesmo tempo, um texto crítico. É a representação } \\
\text { gráfica de um assunto conhecido dos leitores } \\
\text { segundo a visão crítica do desenhista ou do jornal. } \\
\text { [...] É a crítica específica de um fato especíico atual } \\
\text { e não atemporal." (CAVALCANTI, 2008, p. 37). } \\
\text { "Romualdo (200, p. 21) apud Petrini (2012) finaliza } \\
\text { que a charge é compreendida [...] como o texto } \\
\text { visual humorístico que critica um personagem, } \\
\text { fato ou acontecimento político específico. Por } \\
\text { focalizar uma realidade específica, ela se prende } \\
\text { mais ao momento, tendo, portanto, uma limitação } \\
\text { temporal." (PETRINI, 2012, p. 59). }\end{array}$ & $\begin{array}{l}\text { "A charge é uma ilustração que se destina a } \\
\text { transmitir uma mensagem política ou social. [...] } \\
\text { São frequentemente encontrados nas páginas de } \\
\text { editoriais de jornais e revistas. [...] O objetivo de } \\
\text { uma charge é enviar uma mensagem clara, usando } \\
\text { imagens que serão familiares a todas as pessoas } \\
\text { em uma sociedade." (WHAT IS A POLITICAL } \\
\text { CARTOON? [S.1.: s.n., 19--]. }\end{array}$ \\
\hline
\end{tabular}

Fonte: a autora (2015), com base nas referências apresentadas no quadro.

A partir de análises e estudos elaborados por especialistas a respeito dos gêneros dos quadrinhos, podemos estabelecer algumas aproximações e/ou distanciamentos entre 
as comics, comic strips, political cartoons. Observamos, também, que tanto em língua inglesa quanto em língua portuguesa, tais gêneros são definidos de maneiras similares.

Além das caracterizações discutidas até o momento, apresentamos, a seguir, uma descrição (em língua portuguesa e em língua inglesa) do suporte escolhido para veicular os textos produzidos pelos alunos, a partir dos estudos realizados com a SD, conforme demonstrado no Quadro 2:

Quadro 2: Caracterização do suporte no qual os textos dos alunos circularam

\begin{tabular}{|c|c|}
\hline Gibis & Comic books \\
\hline $\begin{array}{l}\text { Os brasileiros conhecem as revistas de histórias } \\
\text { em quadrinhos sob a denominação de "gibi" em } \\
\text { razão do volume elevado de vendas obtidas com a } \\
\text { revista brasileira Gibi Mensal lançada em 1939. O } \\
\text { sucesso da revista decorreu da escolha pela linha } \\
\text { editorial: ela apresentava histórias completas em } \\
\text { vez de séries em continuação, tinha as melhores } \\
\text { séries (com os melhores autores e os personagens } \\
\text { preferidos do público, incluindo os super-heróis) } \\
\text { e publicava as HQs especificamente criadas para } \\
\text { revistas diferente de outras publicações, que eram } \\
\text { constituídas por sequências de tiras ou páginas } \\
\text { dominicais compiladas e montadas." (CHINEN, } \\
2012 \text { apud VIEIRA; CAVEDON, 2013, p. 5). }\end{array}$ & $\begin{array}{l}\text { Revistas em quadrinhos são histórias } \\
\text { seriadas, a maioria são relativamente curtas, } \\
\text { e contam a história de heróis e heroínas da } \\
\text { revista durante um longo período de tempo. } \\
\text { (KELLY, 2014) } \\
\text { O livro em quadrinhos, também chamado de revista } \\
\text { em quadrinhos ou simplesmente quadrinhos, } \\
\text { é uma publicação, popularizada inicialmente } \\
\text { nos Estados Unidos. [...] O termo revista em } \\
\text { quadrinhos se expandiu porque a primeira } \\
\text { revista vendida como uma revista em quadrinhos } \\
\text { reeditou tirinhas já publicadas em jornais. } \\
\text { Apesar do seu nome, as revistas em quadrinhos } \\
\text { não são necessariamente em tom humorístico, } \\
\text { e apresentam histórias em todos os gêneros. } \\
\text { (COMIC BOOK, [S.1.: s.n., 19--]) }\end{array}$ \\
\hline
\end{tabular}

Fonte: a autora (2015), com base nas referências apresentadas no quadro 2.

De acordo com as descrições apresentadas no Quadro 2, vemos que, tanto em língua portuguesa quanto em língua inglesa (mais especificamente nos Estados Unidos), o termo empregado para nomear um dos suportes de publicação dos quadrinhos tem relação com as suas primeiras publicações. No Brasil, conhecemos esse suporte como gibi, por ter sido esse o nome dado à primeira revista onde se publicaram os quadrinhos. Nos Estados Unidos, o termo comic books é empregado até hoje também devido ao fato de que a primeira revista de quadrinhos publicou reedições de comic strips. Além disso, ambos se caracterizam pela publicação de histórias completas, seriadas, não muito longas.

Observando o percurso histórico dos gêneros dos quadrinhos, a publicação considerada como a responsável pela popularização das histórias em quadrinhos - The Yellow Kid - foi veiculada, inicialmente, em dois jornais, nos Estados Unidos. Esse 
fato vem comprovar, de certa maneira, a afirmação de Mendonça (2010) de que as HQs surgiram na periodicidade dos jornais, onde permanecem até hoje, mas tendo também expandido suas possibilidades de veiculação social.

Levando em consideração que a SD foi construída a partir de três gêneros dos quadrinhos - comics, comic strips, political cartoons -, julgamos importante retomar algumas especificidades, estabelecendo comparações entre os três gêneros.

Uma dessas especificidades relaciona-se ao número de painéis que compõem o texto. Com relação às tirinhas (comic strips), Catto e Hendges (2010), Mattar (2010) mencionam a quantia compreendida entre três e quatro painéis. Nicolau (2010, p. 9) afirma que a "tirinha tem como característica básica o fato de ser uma piada curta de um, dois, três ou até quatro quadrinhos e, geralmente, envolve personagens fixos: um personagem principal em torno do qual gravitam outros". Ainda com relação ao número de painéis, Mendonça (2010, p. 214) afirma que as tiras são "um subtipo da HQ; mais curtas (até 4 quadrinhos) e, portanto de caráter sintético [...]". Dessa forma, entendemos que, ao apresentar até quatro painéis, teremos, de acordo com os estudos acima, o gênero textual "tirinhas", ou, de acordo com a terminologia empregada por nós, comic strips.

Mendonça (2010) subdivide as tiras em sequenciais (aquelas que têm continuidade em outras edições) e fechadas (aquelas que se finalizam no mesmo dia). As tiras fechadas, por sua vez, classificam-se em: I) tiras-piada (obtém-se o humor a partir do emprego de estratégias discursivas); II) tiras-episódio (o humor é obtido ao se desenvolver determinada temática em situações em que são realçadas algumas características das personagens).

As comic strips, sejam as classificadas como tiras-piada ou tiras-episódio, circulam socialmente por meio do jornal, o qual é considerado pelos estudos aqui mencionados como o suporte primeiro desse gênero, mas também começam a encontrar outros caminhos para chegarem até aos leitores, conforme se afirma em Mattar (2010, p. 50):

[...] as tiras têm como suporte principal o jornal impresso ou revistas e livros (edições de luxo), mas como o acelerado desenvolvimento das novas tecnologias de informação e comunicação, as formas de comunicação mediadas pelo computador têm propiciado o surgimento de novos processos de interação, como jornais on-line e até mesmo sites especializados em TQs.

Quanto às histórias em quadrinhos (comics), Barreto Freire (2007, p. 30) afirma que cada página "é normalmente composta de seis a nove enquadres retangulares chamados painéis". 
É importante também perceber que as comic strips, com uma função comunicativa básica de entretenimento, abordam temas variados do cotidiano, os quais podem ou não estar relacionados a acontecimentos registrados pela imprensa, abrangendo, assim, faixas etárias diversas, de acordo com Mattar (2010). Contudo, Nicolau (2010) amplia esse conceito básico de entretenimento, ao afirmar que as tirinhas estabelecem um discurso que tanto pode abranger o trivial, cotidiano, como o irônico, o filosófico, mantendo uma participação ativa na imprensa, ora com temáticas banais, ora sociais, politicas, filosóficas. $\mathrm{O}$ autor ainda complementa afirmando que "Sua intenção de entreter traz implícito o questionamento, a denúncia e mesmo a autocrítica." (NICOLAU, 2010, p.9).

Por sua vez, as histórias em quadrinhos (comics) apresentam também a possibilidade de serem utilizadas como forma de entretenimento, tal qual ocorre com as tirinhas (comic strips). Mas, além disso, de acordo com Eisner (1999 apud MENDONÇA, 2010, p. 222), as histórias em quadrinhos (comics) também podem ser usadas com o intuito de apresentarem "instruções técnicas, condicionamentos de atitudes, e story board (usadas para fazer a ponte entre o roteiro de filme e a fotografia final, na publicidade e no cinema)". A referida autora também menciona que a utilização das histórias em quadrinhos (comics) com o intuito de proporcionar condicionamento de atitudes é bastante frequente em vários países, inclusive no Brasil.

Portanto, afirmamos que o emprego de um gênero para um agir sócio-históricoculturalmente situado requer que conheçamos as especificidades desse gênero, conforme asseverado por Pinto (2011, p. 125):

[...] conhecer um gênero textual é conhecer suas condições de uso, sua adequação ao contexto social e as possibilidades de materialização que requerem operações de contextualização e de textualização que levam o locutor a tomar decisões em relação à estrutura e ao estilo composicional do texto.

Desse modo, após as discussões em torno das diferenças/semelhanças entre os gêneros dos quadrinhos focalizados na $\mathrm{SD}$, tomamos por base, ainda, as considerações de Cristovão, Durão e Nascimento (2007) sobre a importância de os leitores compreenderem as convenções das HQ para que possam realizar sua leitura de forma mais proveitosa. Partindo desse mesmo entendimento, defendemos que os gêneros dos quadrinhos carecem de um trabalho mais sistematizado em sala de aula, de modo que suas características sejam melhor compreendidas pelos alunos, a ponto de ajudar-lhes na leitura e compreensão de tais textos, assim como na sua produção, como é o caso deste trabalho. Dessa forma, com 
base nos estudos de experts dos gêneros dos quadrinhos sintetizamos, no Quadro 3, os elementos discursivos constitutivos ${ }^{6}$ de tais gêneros.

Quadro 3: Características discursivas dos gêneros dos quadrinhos

\begin{tabular}{|c|c|}
\hline Elemento & Descrição \\
\hline Sarjeta & $\begin{array}{l}\text { "Espaço compreendido entre os quadros e, segundo McCloud (2005: 66), é } \\
\text { responsável pela magia e mistério que existem na essência dos quadrinhos." } \\
\text { (MOTTA, 2009, p. 30). }\end{array}$ \\
\hline Conclusão & $\begin{array}{l}\text { "A mente, observa McCloud (2005: } 88-89 \text { ), preenche as lacunas entre as } \\
\text { sarjetas, este preenchimento psicológico é denominado conclusão." (MOTTA, } \\
2009, \text { p. } 30) \text {. }\end{array}$ \\
\hline Balões & $\begin{array}{l}\text { "Cagnin (1975: 120) afirma que os balões podem ser diversos e assumirem } \\
\text { infinitas formas, conforme a criatividade e necessidade do desenhista." } \\
\text { (MOTTA, 2009, p. 36). }\end{array}$ \\
\hline Tempo e timing & $\begin{array}{l}\text { O tempo é uma sequência de quadrinhos com elipse, que requer do leitor } \\
\text { maior percepção e conclusão de leitura, enquanto timing é a denominação da } \\
\text { sequência mais detalhada em quadros e que poupa ao leitor algumas conclusões } \\
\text { mentais óbvias para a sequência narrativa." (MOTTA, 2009, p. 39). }\end{array}$ \\
\hline Ângulos & $\begin{array}{l}\text { Há quatro posições básicas da imagem, do ponto de vista do observador: de } \\
\text { frente, de trás, de cima (plongé), de baixo (contre-plongé). (MOTTA, 2009, } \\
\text { p. } 41 \text { ). }\end{array}$ \\
\hline \multirow[t]{2}{*}{ Plano pictórico } & $\begin{array}{l}\text { Analisando as possibilidades que podem haver em relação à distância entre o } \\
\text { observador e o objeto, Motta menciona três delas, as quais considera as mais } \\
\text { comuns: 'em primeiro plano (close up) possibilitando melhor visualização } \\
\text { do rosto'; 'em plano médio, mostrando a figura até o meio do peito ou até } \\
\text { a cintura'; 'em plano geral ou panorâmico, mostrando tanto os personagens }\end{array}$ \\
\hline & quanto o cenário’. (MOTTA, 2009, p. 41). \\
\hline $\begin{array}{ll}\text { Pictogramas } & - \\
\text { metáforas visuais e } \\
\text { linhas cinéticas }\end{array}$ & $\begin{array}{l}\text { São duas as categorias icônicas que podem ser utilizadas com o intuito de } \\
\text { sugerir o movimento nas HQ: A) 'motivada por alguma semelhança com o real } \\
\text { - poeirinha nos pés dos personagens (simbolizando corrida), fumacinha saindo } \\
\text { da cabeça (simbolizando raiva), saliva nos cantos da boca (simbolizando } \\
\text { desejo) etc.'; ou B) 'motivada por unidades linguísticas - cobrinhas, sapos, } \\
\text { flechas e caracóis (simbolizando xingamento - dizer cobras e lagartos), etc.' } \\
\text { (MOTTA, 2009, p. 42). }\end{array}$ \\
\hline $\begin{array}{l}\text { Características } \\
\text { paralinguísticas }\end{array}$ & Expressões faciais, gestos, posturas. (STUTZ; BIAZI, 2007, p. 1232). \\
\hline
\end{tabular}

\footnotetext{
${ }^{6}$ Esclarecemos que esses elementos serão apenas relacionados, com o intuito de dar ao leitor uma noção sobre a complexidade que envolve a elaboração desses gêneros.
} 


\begin{tabular}{|c|c|}
\hline Vinhetas & $\begin{array}{l}\text { Constitui cada momento expresso por meio de uma ilustração, de um conjunto } \\
\text { de momentos significativos que constitui uma HQ. (SANTOS, 2002, p. 20). }\end{array}$ \\
\hline Painel/Quadros & $\begin{array}{l}\text { “Os quadrinhos }[. . .] \text { servem como 'moldura' para o cenário, os personagens } \\
\text { e as legendas e sua principal função é separar as vinhetas.” (CRISTOVÃO; } \\
\text { DURÃO; NASCIMENTO, 2007, p. 39). } \\
\text { É considerado por Eisner como parte da linguagem não-verbal, devido aos } \\
\text { significados que pode trazer ao texto: I) quadros retangulares com traçado } \\
\text { reto = sugerem que as ações estão no tempo presente; II) estando modificado } \\
\text { pode designar recordação ou sonho do personagem, sendo o traçado sinuoso } \\
\text { ou ondulado os mais comuns como indicadores do passado; III) ausência do } \\
\text { quadro dá ideia de espaço ilimitado. (SANTOS, 2002, p. 20). }\end{array}$ \\
\hline Legenda & $\begin{array}{l}\text { "Aparece geralmente no topo do painel, podendo também vir abaixo, acima } \\
\text { ou do lado esquerdo. Normalmente apresenta a voz do narrador e tem a função } \\
\text { de acrescentar informação aos diálogos contidos nos painéis." (BARRETO; } \\
\text { FREIRE, 2007, p. 33). }\end{array}$ \\
\hline Título/Subtítulo & $\begin{array}{l}\text { "O título contribui para a produção de sentido por sugerir informações e } \\
\text { intensificar a relação entre emissor/enunciador e receptor/destinatário." } \\
\text { "O subtítulo, uma explicação extra sobre a história antes mesmo de que seja } \\
\text { lida, representando a opinião do narrador." } \\
\text { (CRISTOVÃO; DURÃO; NASCIMENTO, 2007, p. 41). }\end{array}$ \\
\hline
\end{tabular}

Fonte: a autora (2015), com base nas referências apresentadas no próprio quadro.

O Quadro 4, elaborado com base em Cristovão, Durão e Nascimento (2007), Mattar (2010) e Leal (2011) intenciona expor alguns elementos linguístico-discursivos constitutivos dos gêneros comics, comic strip e political cartoon.

Quadro 4: Elementos linguístico-discursivos dos gêneros dos quadrinhos

\begin{tabular}{|c|}
\hline Elementos linguístico-discursivos \\
\hline Onomatopeia utilizada de modo a enfatizar o visual. \\
\hline Pontuação utilizada como recurso semântico para manifestar surpresa, indignação etc. \\
\hline $\begin{array}{l}\text { Tamanho e tipo da fonte variados de acordo com as sensações (medo, raiva, hesitação etc.) que se } \\
\text { pretende demonstar. }\end{array}$ \\
\hline Tipos de frases curtas empregadas como representativas de sequências dialogais. \\
\hline Linguagem informal característica da oralidade. \\
\hline $\begin{array}{l}\text { Léxico variado de acordo com as temáticas envolvidas, tendo um destaque maior para a presença de } \\
\text { adjetivos e interjeições. }\end{array}$ \\
\hline Reduções vocabulares típicas da oralidade. \\
\hline
\end{tabular}


Tempos verbais diversificados, com maior incidência dos tempos presente, passado e futuro simples.

Figuras de linguagem utilizadas na construção do humor e/ou crítica.

Vozes representativas das personagens, do narrador, do autor.

Narração como tipo de discurso privilegiado, principalmente nas comics/comic strips e mundo discursivo do expor mais relacionado aos political cartoons. Sequências narrativa e dialogal.

Fonte: a autora (2015), com base em Cristovão, Durão e Nascimento (2007), Mattar (2010) e Leal (2011).

Tomando por base, portanto, a descrição e discussões acerca dos gêneros comics, comic strips, political cartoon, realizados por nós, a partir de estudos já empreendidos, apresentamos o Quadro 5, o qual contempla, de maneira sintética, as características contextuais (voltadas ao trabalho com as capacidades de ação e de significação), discursivas (enfocando as capacidades discursivas) e linguístico-discursivas (tratando dos elementos linguístico-discursivos) dos referidos gêneros.

Quadro 05: Características dos gêneros comics, comic strips, political cartoons

Características discursivas (relacionadas às $\mathrm{CD}$ ) dos gêneros comics, comic strips, political cartoons $\rightarrow$ Comics/comic strips: narrativas icônico-verbais, prevalecendo o discurso da ordem do narrar (narração e discurso interativo com sequências narrativa e dialogal). $\rightarrow$ Political cartoon: sequência narrativa é opcional, mais relacionado ao mundo discursivo do expor.

RECURSOS NÃO VERBAIS E PARALINGUÍSTICOS

$\rightarrow$ Painéis: normalmente, nas comics, cada página é composta por mais de cinco painéis; nas comic strips, cada uma compreende três ou quatro painéis, em média; nos political cartoons, geralmente, há apenas um quadro.

$\rightarrow$ Recursos paralinguísticos que colaboram na construção dos significados: expressões faciais, gestos, posturas dos personagens.

$\rightarrow$ Linhas cinéticas e metáforas visuais (poeirinha nos pés, fumacinha saindo da cabeça, cobrinhas/sapos/ caracóis simbolizando o xingamento, etc.).

$\rightarrow$ Balões: espaço em que a maior parte do texto verbal está inserido, podendo receber várias denominações de acordo com sua função.

$\rightarrow$ Legenda: representa a voz do narrador, acrescenta informações extras às falas dos personagens.

$\rightarrow$ Fonte e tamanho das letras diversificados.

$\rightarrow$ Imagens coloridas ou não complementam os significados dos recursos verbais.

$\rightarrow$ Os títulos são presentes nas comics. Nas comic strips e political cartoons não há essa frequência.

$\rightarrow$ Outros elementos constitutivos dos gêneros dos quadrinhos: sarjeta, conclusão, tempo e timing, ângulos, plano pictórico, vinhetas.

Características linguístico-discursivas (relacionadas às CLD) dos gêneros comics, comic strips, political cartoons

$\rightarrow$ A inserção das vozes (dos personagens, do autor, do narrador) é apresentada nos balões ou legendas.

$\rightarrow$ Presença de conectivos temporais (era uma vez, certo dia, etc.) e espaciais (na escola, na vizinhança, aqui, lá, etc.).

$\rightarrow$ Vocabulário diversificado - coerente às personagens e aos temas - com uma variedade mais informal, 
coloquial, com frases curtas, expressões idiomáticas, reduções vocabulares.

$\rightarrow$ Tempo verbal diversificado, com predomínio do presente, passado, futuro simples, presente contínuo.

$\rightarrow$ Presença de adjetivos para caracterizar ambientes, personagens, situações.

$\rightarrow$ Sintagmas nominais relacionados aos conteúdos.

$\rightarrow$ Presença de interjeições.

$\rightarrow$ Onomatopeias - deixando a narrativa mais significativa.

$\rightarrow$ Sinais de pontuação - colaboram na representação da oralidade.

$\rightarrow$ Coesão nominal por meio de anáforas pronominal e nominal.

$\rightarrow$ Figuras de linguagem (ironia, hipérbole, personificação, metáfora).

Características contextuais (relacionadas às CA e CS) - direcionadas aos gêneros comics, comic strips, political cartoons.

$\rightarrow$ Comic strips, comics: gêneros escritos compostos por dois códigos, o verbal e o iconográfico, pertencentes tanto à esfera artística quanto jornalística; podem tratar de temas universais do cotidiano ou, ainda, de temáticas relacionadas a fatos sociais que circulam na imprensa.

$\rightarrow$ Political cartoons: consiste na crítica humorística, segundo a ótica do desenhista, por meio da reprodução gráfica (imagem ou imagem + texto) de uma notícia, já conhecida do público.

PRÁTICA SOCIAL

$\rightarrow$ Comics, comic strips: comunicar ideias ou histórias por meio de palavras e figuras com o objetivo de divertir, satirizar, ironizar, podendo ainda se configurar como veiculador de instruções técnicas, condicionamentos de atitudes e story board.

$\rightarrow$ Political cartoon: relacionados a fatos que circulam na imprensa; objetivam expressar opiniões, críticas.

CONTEXTO DE PRODUÇÃO

$\rightarrow$ Gêneros surgidos na peridiocidade dos jornais, as comics e as comic strips passaram, com o tempo, a figurar também em revistas especializadas como os gibis e outras revistas diversificadas. Os political cartoons, também originados em jornais, possuem espaço em revistas mensais de notícias, boletins informativos empresariais, jornais. Todos os três gêneros podem, também, ser produzidos e circularem em ambientes virtuais.

$\rightarrow$ O emissor das comics, comic strips - os quadrinistas - criam suas histórias, muitas vezes, a partir de relações estabelecidas com seu contexto social, cultural mais proximo. O emissor de political cartoons os cartunistas - são humoristas geralmente ligados ao mesmo suporte onde é publicado (jornais, revistas, sites etc.). $\rightarrow$ Personagens: nas comics e comic strips: apresentam-se com gestos e humores humanos, podendo ser fixos. Os political cartoons também apresentam personagens com gestos e humores humanos, mas não contam com personagens fixos.

Fonte: a autora (2015)

Entendemos que, tanto os elementos contextuais, como os discursivos e os linguístico-discursivos não serão esgotados em uma única SD, já que o ensino com base em gêneros pressupõe uma organização curricular que permita uma progressão de forma espiralada dos conteúdos. Contudo, para o professor que se propõe a elaborar uma SD, é essencial ter clareza sobre como um gênero se constitui para uma circulação em determinada esfera social. Esse conhecimento, viabilizado a partir do MDG, vai lhe possibilitar fazer as escolhas necessárias e adequadas ao contexto de ensino e aprendizagem em que está inserido, objetivando um ensino de língua que suplante um enfoque apenas gramatical ou ainda uma gramaticalização do gênero. 
Nesse sentido, o procedimento Sequência Didática, com base nos aportes genebrinos e com vistas ao desenvolvimento das Capacidades de Linguagem dos alunos, é um caminho promissor a ser trilhado.

\section{METODOLOGIA}

Partindo dos pressupostos teóricos já apresentados, e nos inserindo no campo das pesquisas em Linguística Aplicada, definimos nosso trabalho como um estudo de cunho qualitativo interpretativista à luz do ISD, com foco em uma análise documental, ao nos voltarmos para a análise da SD elaborada com base em três gêneros dos quadrinhos.

A SD é composta de 68 atividades, as quais se subdividem em 117 questões? Há a presença de três textos em vídeos (animated cartoons) e nove textos escritos dos gêneros enfocados (comics, comic strips, political cartoons), um curta biografia do autor de Garfield, nove textos explicativos sobre os gêneros enfocados e suas características, um texto informativo sobre o tema voluntariado, um texto informativo sobre o tema (biodiesel) tratado nos political cartoons. Constam, também, um jogo (na seção Fun and games), uma lista de constatação da produção escrita (na seção Working on your final text production-evaluation and self-check), duas atividades de análise crítica geral da unidade (na seção Critical Thinking). Além disso, a produção escrita aparece em três momentos: a primeira, sendo uma produção inicial de tema livre, do gênero dos quadrinhos; a segunda, continuando com o mesmo gênero, mas já definindo o tema, o suporte, o objetivo do texto; e o terceiro momento - a produção final - em que se dá a reescrita do texto produzido no segundo momento.

Como procedimentos de análise apresentamos o Plano Textual Global da SD de modo a estabelecer as relações possíveis entre suas seções e as etapas do procedimento $\mathrm{SD}$, bem como com os elementos ensináveis dos gêneros enfocados.

\section{Análise dos dados}

Apresentamos, neste tópico, a forma como a $\mathrm{SD}^{8}$ está organizada, ou seja, o seu Plano Textual Global, descrevendo as partes que a compõem, de modo a estabelecer uma

\footnotetext{
${ }^{7}$ Chamamos de atividades os enunciados que indicam um exercício mais amplo; e de questões, as subdivisões encontradas nessas atividades, quando elas nos remetem a diferentes capacidades de linguagem.
}

${ }^{8}$ A SD pode ser consultada, na íntegra, no Dissertação já mencionada no início deste artigo. 
relação com a estrutura de base de uma SD.

Organizada em 21 páginas e com o título "Comics and cartoons: a funny way of seeing the real life - Comprehending the implicit through comics",", a SD explora os gêneros textuais comics, comic strips, political cartoon, os quais estão voltados para um agir dos alunos visando à realização de uma campanha de trabalho voluntário com enfoque local (escolar ou da comunidade).

A primeira página da SD, conforme demonstrado na Figura 2, apresenta o material e suas especificidades: o título, os gêneros textuais que serão abordados e os conteúdos advindos de tais gêneros, a justificativa para o estudo, os objetivos, o tema principal que norteará o agir geral praxeológico e linguageiro dos alunos.

Figura 2: Página inicial da SD

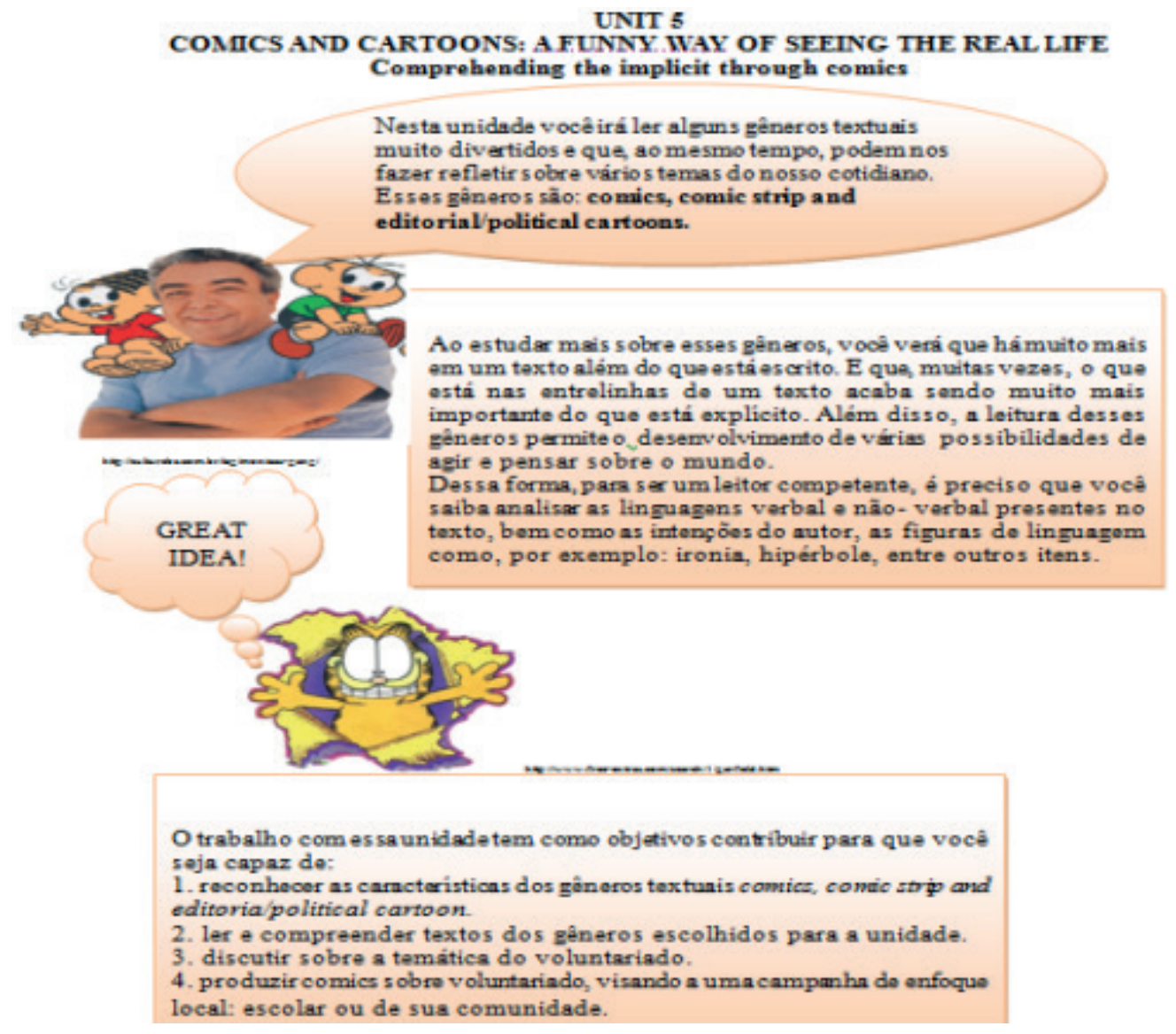

Fonte: a autora (2015).

\footnotetext{
${ }^{9}$ Histórias em quadrinhos e charges: uma maneira engraçada de ver a vida real - compreendendo o implícito através das histórias em quadrinhos.
} 
A SD procura, através dos textos introdutórios de sua página inicial, incentivar o aluno para o estudo do gênero, fornecendo dicas sobre quais podem ser as funções desses gêneros e como eles precisam ser lidos para que atinjam os objetivos a que se propõem. Apresenta, também, a proposta de ação praxeológica (desenvolver uma campanha de enfoque local: escolar ou de sua comunidade) e linguageira (produzir comics sobre voluntariado, visando a uma campanha de enfoque local: escolar ou de sua comunidade) a ser desenvolvida a partir desse estudo. Na segunda página, contempla o Self-assessment ${ }^{10}$, o qual é composto por 11 itens em que o aluno deverá assinalar Yes, No, Partially ${ }^{11}$. Essa atividade será feita em dois momentos: antes de iniciar as atividades presentes no material e após o encerramento de todas elas, conforme consta na Figura 3:

Figura 3: Segunda página da SD - Self-assessment

\section{SELF-ASSESSMENT}

Tick $(\sqrt{ })$ what you are able to do in Enghish before and after studying this unit.

\begin{tabular}{|c|c|c|c|c|c|c|}
\hline GOALS & \multicolumn{3}{|c|}{ BEFORE STUDYING } & \multicolumn{3}{|c|}{ AFTER STUDYING } \\
\hline I am able to ... & YES & No & PARTIALIY & YES & No & PARTIALLY \\
\hline $\begin{array}{l}\text {... recognize and read comic strips } \\
\text { and comics. }\end{array}$ & & & & & & \\
\hline $\begin{array}{l}\ldots \text { recognize and read political } \\
\text { cartoons. }\end{array}$ & & & & & & \\
\hline $\begin{array}{l}\text {... identify the characteristics of } \\
\text { comic strips and comics. }\end{array}$ & & & & & & \\
\hline $\begin{array}{l}\text {... identify the characteristics of } \\
\text { political cartoons. }\end{array}$ & & & & & & \\
\hline $\begin{array}{l}\text { recognize the different kind of } \\
\text { balloons and their use. }\end{array}$ & & & & & & \\
\hline $\begin{array}{l}\text {.. read the implicit in comics, } \\
\text { comic strips and political } \\
\text { cartoons. }\end{array}$ & & & & & & \\
\hline $\begin{array}{l}\text {...recognize and use } \\
\text { onomatopoeias. }\end{array}$ & & & & & & \\
\hline $\begin{array}{l}\text {... recognize and use figures of } \\
\text { speech. }\end{array}$ & & & & & & \\
\hline ... discuss volunteering. & & & & & & \\
\hline $\begin{array}{l}\text {... write comics considering the } \\
\text { genre's characteristics. }\end{array}$ & & & & & & \\
\hline ... evaluate my own progress. & & & & & & \\
\hline
\end{tabular}

Fonte: a autora (2015).

${ }^{10}$ Autoavaliação.

${ }^{11}$ Sim, não, parcialmente. 
As orientações e explicações trazidas na Página Inicial, bem como a realização do Self-assessment, têm o intuito de contextualizar o processo de ensino que está para ter início, de modo que o aluno tenha ciência do que irá estudar e compreenda o porquê desse estudo. O Self-assessment, mais especificamente, ao mesmo tempo em que apresenta de forma indireta os conteúdos propostos na SD, também possibilita que o aluno se autoavalie. Além disso, nas duas primeiras páginas podemos encontrar, direta ou indiretamente, os objetivos a serem atingidos, a partir do estudo proposto pela SD.

As duas páginas iniciais, portanto, apresentaram a explicitação e a justificativa para o estudo que seria empreendido, principalmente ao se referirem ao projeto de classe a ser desenvolvido, indo ao encontro do que Dolz, Noverraz e Schneuwly (2010) denominam de projeto de comunicação, compreendendo a primeira etapa da estrutura de base de uma SD - a apresentação da situação.

Na terceira página têm início os módulos da $\mathrm{SD}$, os quais foram denominados por nós de "seções". Essas seções receberam títulos ${ }^{12}$ de acordo com as especificidades das atividades que as compõem. Excetuando-se as duas primeiras páginas onde encontramos a Apresentação da situação e o Self-assessment, as atividades da SD são organizadas em 21 páginas, distribuídas em 16 seções: Finding out about communicative context; Reflecting about the context and content; Reflecting about the genre; Fun and Games; Reflecting about the content; Reflecting about the text organization; Reflecting about the language; Working on your text production; Reflecting about the content; Working on your text production; Finding out about communicative context; Reflecting about the context; Reflecting about the genre; Reflecting on the content and on the language; Working on your final text production - evaluation and self-check; Critical thinking ${ }^{13}$.

Segue o Quadro 6, o qual permite visualizar a organização interna da SD:

${ }^{12}$ Os títulos dados às seções foram escolhidos, em comum acordo, pelo grupo de professores elaboradores do material didático do CELEM.

${ }^{13}$ Informando-se sobre o contexto comunicativo; Refletindo sobre o contexto e o conteúdo; Refletindo sobre o gênero; Diversão e jogos; Refletindo sobre o conteúdo; Refletindo sobre a organização do texto; Refletindo sobre a língua; Trabalhando na produção de seu texto; Refletindo sobre o conteúdo; Trabalhando na produção de seu texto; Refletindo sobre o conteúdo; Trabalhando na produção de seu texto; Informando-se sobre o contexto comunicativo; Refletindo sobre o contexto; Refletindo sobre o gênero; Refletindo sobre o conteúdo e a língua; Trabalhando na produção final de seu texto, avaliação e autoavaliação; Reflexão crítica. 
Quadro 6: Organização Interna da SD

\begin{tabular}{|c|c|c|}
\hline $\begin{array}{c}\text { Seção } 1 \\
\text { Finding out about } \\
\text { communicative context }\end{array}$ & $\begin{array}{c}\text { Seção } 2 \\
\text { Reflecting about the context } \\
\text { and content }\end{array}$ & $\begin{array}{c}\text { Seção } 3 \\
\text { Reflecting about the genre }\end{array}$ \\
\hline $\begin{array}{c}\text { Inclui } 1 \text { animated cartoon }{ }^{14} \\
\text { (Garfield Quickie - Slave } \\
\text { to the passions), } 1 \text { curta } \\
\text { biografia sobre o autor de } \\
\text { Garfield, } 6 \text { atividades e } 12 \\
\text { questões. }\end{array}$ & $\begin{array}{c}\text { Inclui } 1 \text { comic strip (Garfield } \\
\text { Quickie - Slave to the } \\
\text { passions), } 3 \text { atividades e } 11 \\
\text { questões. }\end{array}$ & $\begin{array}{l}\text { Inclui } 1 \text { texto explicativo } \\
\text { sobre o gênero comic strip, } 5 \\
\text { atividades e } 8 \text { questões. }\end{array}$ \\
\hline $\begin{array}{c}\text { Seção } 4 \\
\text { Fun and Games }\end{array}$ & $\begin{array}{c}\text { Seção } 5 \\
\text { Reflecting about the content }\end{array}$ & $\begin{array}{c}\text { Seção } 6 \\
\text { Reflecting about the text } \\
\text { organization }\end{array}$ \\
\hline $\begin{array}{l}\text { Inclui orientações para } \\
\text { realização de um game, } \\
\text { constituindo-se em } 1 \text { atividade } \\
\text { e } 1 \text { questão. }\end{array}$ & $\begin{array}{l}\text { Inclui } 1 \text { animated cartoon } \\
\text { (Garfield in a Big Date), } 2 \\
\text { atividades e } 2 \text { questões. }\end{array}$ & $\begin{array}{l}\text { Inclui } 1 \text { comics (Monica's } \\
\text { gang), } 4 \text { textos explicativos } \\
\text { sobre o uso das imagens, } \\
\text { sobre os balões, sobre } \\
\text { diferença entre comic book e } \\
\text { comic strip e sobre painéis, } 15 \\
\text { atividades e } 20 \text { questões. }\end{array}$ \\
\hline $\begin{array}{c}\text { Seção } 7 \\
\text { Reflecting about the language }\end{array}$ & $\begin{array}{l}\text { Seção } 8 \\
\text { Working on your text } \\
\text { production }\end{array}$ & $\begin{array}{c}\text { Seção } 9 \\
\text { Reflecting about the content }\end{array}$ \\
\hline $\begin{array}{c}\text { Inclui } 1 \text { texto explicativo } \\
\text { sobre onomatopéias, } 1 \\
\text { animated cartoon enfocando } \\
\text { onomatopéias, } 5 \text { atividades e } \\
6 \text { questões. }\end{array}$ & $\begin{array}{c}\text { Apresenta as orientações } \\
\text { para a primeira atividade de } \\
\text { escrita, incluindo } 1 \text { atividade } \\
\text { e } 1 \text { questão. }\end{array}$ & $\begin{array}{c}\text { Inclui } 1 \text { comics (Monica’s } \\
\text { gang), } 1 \text { texto informativo } \\
\text { sobre trabalho voluntário, } \\
1 \text { comic strip sobre } \\
\text { voluntariado, } 7 \text { atividades, } 9 \\
\text { questões. }\end{array}$ \\
\hline
\end{tabular}

${ }^{14}$ Desenho animado. 


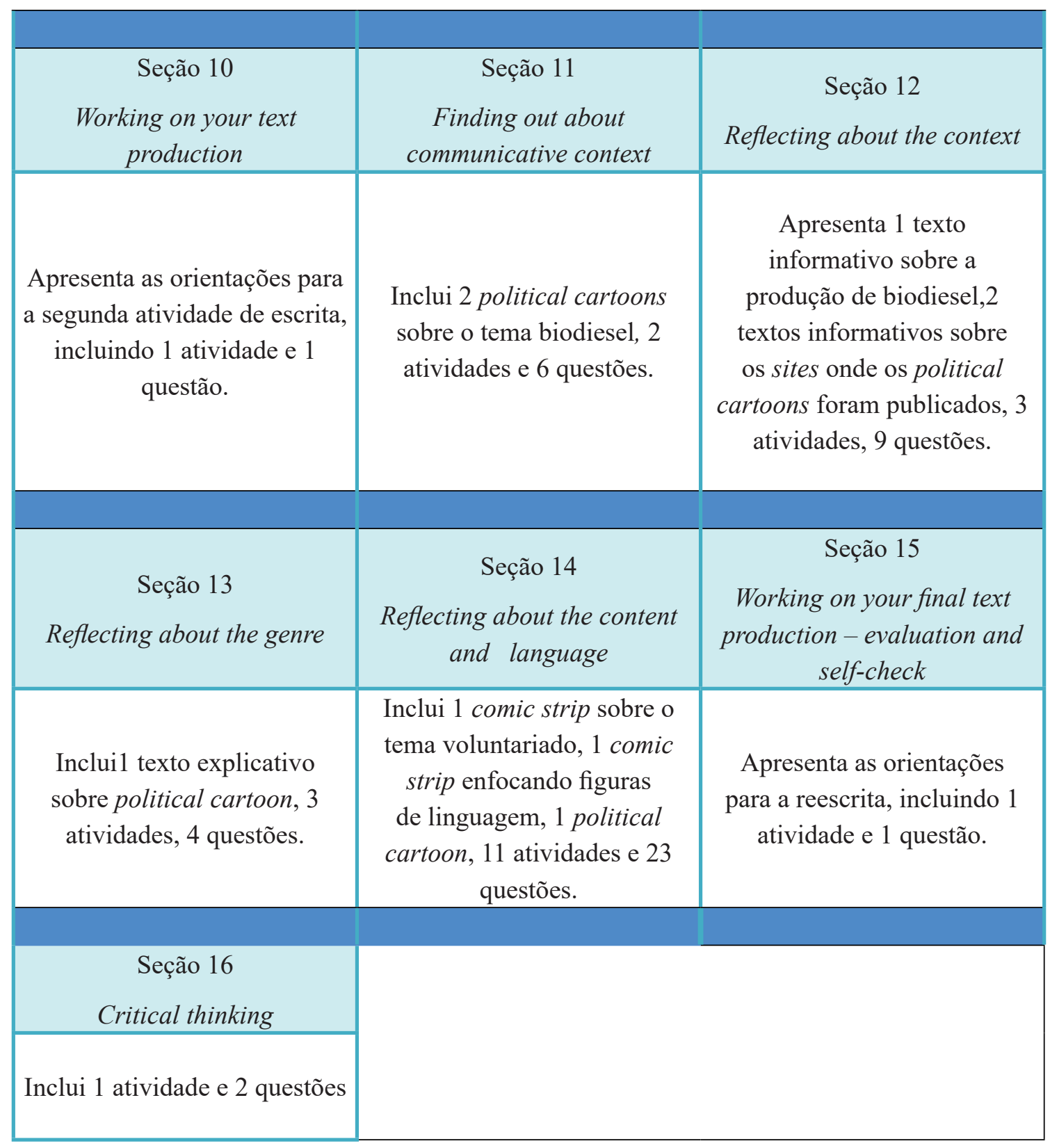

Fonte: a autora (2015).

Ao retomarmos a estrutura de base de uma SD proposta por Dolz, Noverraz e Schneuwly (2010), temos a etapa da produção inicial como um momento anterior ao início dos módulos. Contudo, consideramos que, em se tratando do ensino de língua estrangeira (o que envolve um conhecimento linguístico de maior dificuldade em comparação à língua materna) e também levando-se em conta as características dos gêneros enfocados, 
a atividade em torno da produção inicial deve ser analisada e reestruturada de forma a atender melhor essas especificidades. Em nosso caso, cientes da complexidade que envolve os gêneros dos quadrinhos, assim como das possíveis dificuldades dos alunos em relação à atividade de produzir um texto em língua inglesa, optamos por iniciar os módulos antes de se realizar a produção escrita inicial ${ }^{15}$. Assim, a atividade considerada por nós como a produção inicial está inserida na oitava seção da SD - Working on your text production, conforme demonstrado na Figura 4:

Figura 4: Produção Inicial - I

\section{8 - WORKING ON YOUR TEXT PRODUCTION}

Would you like to be an author of comics or comic strips? Try to create a story using

the characters of Monica's gang. Go to: http://www.maquinadequadrinhos.com.br/Intro.aspx

Remember to use the content we've learned until now: panels, onomatopoeia, balloons, images. Your text content will be free. Let your imagination free to create.

Fonte: a autora (2015)

A retomada da escrita, considerando-se o caráter processual envolvido neste trabalho de produção escrita, comprova-se a seção 10, a qual solicita aos alunos que retomem os estudos realizados ao longo dos módulos e iniciem a produção escrita de modo a atender o que foi proposto na etapa da Apresentação da Situação, na primeira página da SD. A Figura 5 demonstra essa continuidade com a atividade de escrita como processo:

\footnotetext{
${ }^{15}$ Quanto a esta organização, defendemos que outros arranjos podem ser feitos, sempre com vistas a atender as especificidades e as necessidades dos alunos.
} 
Figura 5: Produção Inicial - II

\section{0 - WORKING ON YOUR TEXT PRODUCTION}

Throughout this unit you have studied some texts of comics and comic strip. Now it is time to put the knowledge you acquired about these genres into practice. Do it by writing comics text. Your text will be written in a support called FLY. Look at an example of this support:

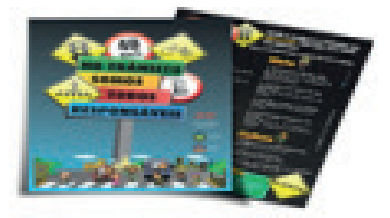

htto://www. pixelideias.blog

How about thinking of producing a volunteer campaign at your school? Let's plan this campaign...

- Discuss with your classmates what kind of volunteering work could be done in your school/ in your neighborhood. Think about the problems that have to be discussed with all your friends and determine the campaign theme.

- Organize your group and distribute the functions.

- Choose the characters of your text. You may draw or glue pictures that represent the characters.

-Give creative names to them. Think of their characteristics. They must be present throughout the story.

- Remember that your text will be comics, so pay attention to: balloons, panels, dialogues, figures of speech, image, etc. Write the first version of the text. These are your first steps. Do this part of work and give it to your teacher.

Fonte: a autora (2015).

Após a Seção 10, outras seções são trabalhadas, constituindo também o que é denominado por Módulos, a partir do esquema da SD. Chegando, então, à etapa da Produção Final, presenta na Seção 15, conforme demonstrado na Figura 6: 
Figura 6: Produção Final

\section{5 - WORKING ON YOUR FINAL TEXT PRODUCTION} EVALUATION AND SELF-CHECK

1. In this last part of the unit, you are going to end your text production for your campaign. With your group, read the text you have produced before and use the checklist to analyze it:

\begin{tabular}{|l|l|l|l|}
\hline & YES & NO & PARTIALLY \\
\hline 1. Are there interesting characters? & & & \\
\hline 2. Did you give names to your characters? & & & \\
\hline 3. Did you distribute the text inside the panels? & & & \\
\hline 4. Are there onomatopoeias? & & & \\
\hline 5. Did you use different kinds of balloons? & & \\
\hline 6. Are there dialogues between the characters? & & \\
\hline 7. Are there figures of speech: exaggeration, irony, personification? & & & \\
\hline 8. Is the theme about volunteering? & & & \\
\hline $\begin{array}{l}\text { 9. Did you present a discussion of your school or neighborhood } \\
\text { problem? }\end{array}$ & & & \\
\hline $\begin{array}{l}\text { 10. In your text is there an invitation to an action against this } \\
\text { problem? }\end{array}$ & & & \\
\hline 11. Are there images that illustrate the message of your text? & & & \\
\hline
\end{tabular}

2. At this stage, the pages have to be diagrammed, described the scenes and dialogues finally defined. Then, if there are any characteristics missing, it is time to rewrite your text in order to improve it.

Important: the texts produced will be distributed in your school and also in the community. So, do a nice work!

Fonte: a autora (2015).

A apresentação mais ampla da SD, presente no Quadro 6, permite-nos retomar o conceito de SD, a qual é tida como "[...] um conjunto de atividades escolares organizadas, de maneira sistemática, em torno de um gênero textual oral ou escrito" (DOLZ; NOVERRAZ; SCHNEUWLY, 2010, p.82), com o intuito de dar ao aluno a possibilidade de interagir com práticas de linguagem novas, ou ainda com aquelas tidas como mais difíceis de serem dominadas. O que nos leva a avaliar que a SD em análise exemplifica o ensino organizado de maneira sistemática com base em três gêneros dos quadrinhos, com vistas a um agir praxeológico e linguageiro.

Quanto aos elementos ensináveis dos gêneros em questão, relacionados às características contextuais (voltadas ao trabalho com as capacidades de ação e de significação), discursivas (enfocando as capacidades discursivas) e linguístico-discursivas 
(tratando dos elementos linguístico-discursivos), é possível perceber, pela descrição de cada Seção da SD, presente no Quadro 6, que os três grandes grupos foram atendidos. Ou seja, as atividades contemplam elementos contextuais, discursivos e linguísticodiscursivos, o que pode vir a potencializar o desenvolvimento das Capacidades de Linguagem dos alunos de uma forma integral, distanciando-se de um ensino com foco apenas em gramática, ou vocabulário, ou ainda apenas leitura e compreensão, de forma isolada.

Com relação à escolha do gênero a ser didatizado, de modo a atender às dimensões psicológica, cognitiva, social e didática, a Figura 7 demonstra como a SD atendeu a tais dimensões:

Figura 7: A escolha do gênero e do tema a partir das quatro dimensões

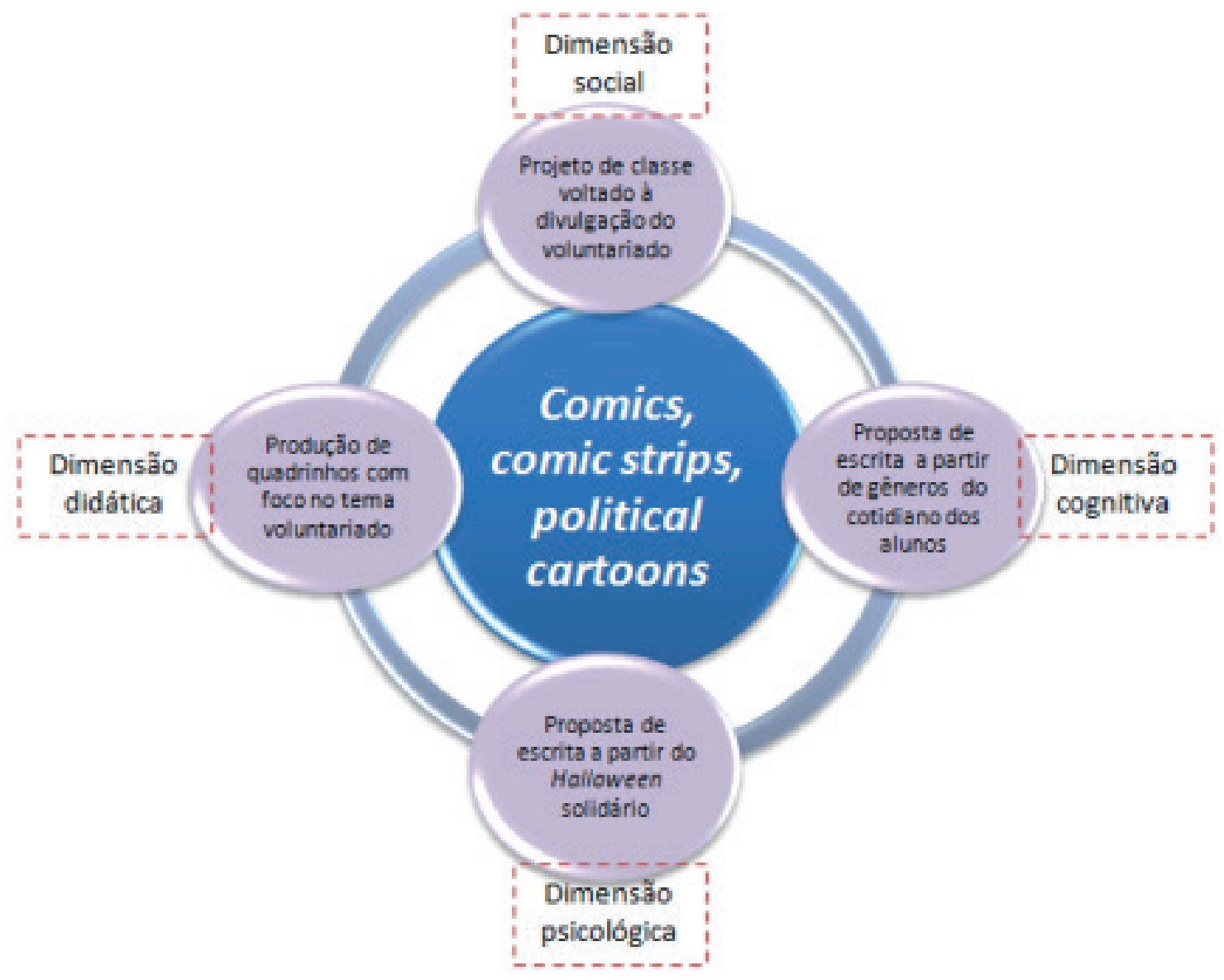

Fonte: a autora (2015) 
Entendemos que a definição de um projeto de classe voltado para a realização de um trabalho voluntário em nível escolar ou da comunidade (dimensão social) se consolidou com a realização de um Halloween solidário ${ }^{16}$, atividade que motivou e despertou o interesse dos alunos (dimensão psicológica) para a realização da produção escrita em forma de comics (dimensão didática), considerando, assim, o nível de conhecimento dos alunos, tanto em relação ao tema quanto ao gênero (dimensão cognitiva).

\section{CONSIDERAÇÕES FINAIS}

A partir das análises aqui apresentadas, podemos concluir que houve uma preocupação em se propor um ensino de língua inglesa pautado pela concepção de ensino com base em gêneros por meio do procedimento Sequência Didática.

Isso também pode ser levado em conta quando observamos que o trabalho com aspectos linguísticos característicos dos gêneros estudados também aparece de forma direcionada para tais gêneros - 14 atividades da SD enfocaram esses aspectos. Fato esse que aponta para uma das diferenças entre este material, elaborado a partir dos aportes teóricos que embasam o procedimento $\mathrm{SD}$, e qualquer outro material que não se pauta pela mesma teoria, pois, no caso desta $\mathrm{SD}$, por exemplo, não houve a preocupação de se inserir conteúdos de ordem gramatical pelo critério de complexidade, como normalmente costumamos encontrar nos livros didáticos. Contrariamente a essa visão de ensino gramatical pautado pela ordem de complexidade, a proposta que se apresenta é que os conteúdos linguístico-discursivos emerjam a partir das necessidades surgidas a partir do estudo de textos de diferentes gêneros, e não o contrário.

Com relação à escrita, constatamos que os objetivos relacionados a essa prática se concretizaram em três momentos, correspondendo a três seções que tratam da atividade de produção escrita. Mas, além disso, por entendermos que não há escrita sem leitura, vinculamos também, de forma indireta, as atividades voltadas para a leitura, bem como as cinco atividades que direcionaram a discussão para a temática do voluntariado como sendo constitutivas e fontes de pesquisa para as atividades de escrita.

Quanto às possibilidades e desafios envolvidos em um processo de elaboração de SD para o ensino de língua inglesa com base em gêneros dos quadrinhos por meio

\footnotetext{
${ }^{16}$ Esta atividade foi proposta em comemoração à data do Halloween. Contudo, recebeu o nome de Supportive Halloween, pois teve o objetivo de arrecadar alimentos não perecíveis e produtos de higiene pessoal para serem entregues ao Lar de Idosos do município, o qual passava por dificuldades financeiras.
} 
do procedimento $\mathrm{SD}$, entendemos que adotar o referencial teórico do ISD e sua vertente pedagógica por meio da SD, pode possibilitar práticas pedagógicas inovadoras e envolventes, sem deixar, contudo, de tratar da questão primordial para a qual as escolas são feitas - promover o desenvolvimento de nossos alunos, em seus vários aspectos. Aspectos esses que envolvem a apropriação do conhecimento científico que lhes possibilitarão compreender e transformar, por meio de ações praxeológicas e linguageiras, o contexto sociocultural em que estão inseridos.

No entanto, também temos a clareza de que o processo de elaboração de uma SD é complexo, demanda tempo, estudo. Assim como ministrar aulas com base nessa perspectiva também exige do professor tempo e condições para planejamento e estudo, tempo e condições para atender seus alunos quando se instaura um processo de produção de texto (oral ou escrito) significativo e não apenas como um produto para se atribuir uma nota. Assim, os desafios que avaliamos existir quando nos propusemos a analisar a SD foco deste estudo, estende-se também a outros gêneros. Sem condições objetivas e subjetivas de trabalho, promover um processo de ensino e aprendizagem significativo, desafiador, focado no desenvolvimento das capacidades de linguagem dos alunos, de forma integrada, continuará limitado a alguns poucos casos em que essas condições possam vir a existir, seja pelo esforço individual de um professor ou de uma escola em particular.

É possível fazer algo diferente quando se pensa no contexto de ensino e aprendizagem de línguas? Sim, é possível! Inúmeros têm sido os estudos que corroboram as possibilidades de transformações ao se organizar o processo de ensino e aprendizagem, com base nos aportes teóricos apresentados neste artigo, assim como a partir de outras perspectivas teóricas, também. Contudo, inúmeros também têm sido os estudos que anunciam e denunciam a necessidade de melhores condições de trabalho para o professor brasileiro. Eis a luta que precisamos travar continuamente. 


\section{REFERÊNCIAS:}

BARRETO-FREIRE, A.M.Elaboração de uma sequência didática centrada no gênero cartum.2007, 81 p. Dissertação (Mestrado) - Universidade Federal da Paraíba, João Pessoa, 2007. Disponível em: <http://www.cchla.ufpb.br/ppgl/wp-content/uploads/2012/11/ images_AnaBarreto.pdf $>$. Acesso em: 20 de junho de 2014.

BRONCKART, J. P. Atividade de linguagem, textos e discursos: por um interacionismo sócio-discursivo. Tradução: Anna Raquel Machado, Péricles Cunha. São Paulo: EDUC, Ed. 2, 2012.

Interacionismo Sócio-discursivo:uma entrevista com Jean Paul Bronckart. Revista Virtual de Estudos da Linguagem - ReVEL. Vol. 4, n. 6, março de 2006. Tradução de Cassiano Ricardo Haag e Gabriel de Ávila Othero. ISSN 1678-8931 [www.revel.inf.br]. Disponível em: <http://www.revel.inf.br/files/entrevistas/revel_6_ entrevista_bronckart_port.pdf $>$. Acesso em 14 de outubro de 2013.

CATTO, N.R.; HENDGES, G.R. Análise de gêneros multimodais com foco em tiras em quadrinho. Signum: Estudos da Linguagem,Londrina, n.13/2,p.193-217, dez.2010.

CAVALCANTI, M. C. C. Multimodalidade e argumentação na charge. Dissertação (Mestrado em Letras) - Universidade Federal de Pernambuco. CAC. Recife, 2008. Disponível em: <http://www.repositorio.ufpe.br/handle/123456789/7504>Acesso em: 20 de junho de 2014.

CHEVALLARD, Y. On didactic transposition theory: some introductory notes. 1989. Disponível em: $<$ http://yves.chevallard.free.fr/spip/spip/rubrique.php3?id_rubrique=6>. Acesso em: 17 janeiro de 2015.

La transposition didactique. Du savoir savant au savoir enseigné. renoble: La pensée sauvage, 1985.

(COMIC BOOK. [S.1.: s.n., 19--]). Disponível em: <https://www.princeton.edu/ achaney/ tmve/wiki100k/docs/Comic_book.html>. Acesso em: 12 de janeiro de 2015.

COMIC STRIP. Dictionary.com Unabridged. [S.1.: s.n., 19--]. Disponível em: <http:// dictionary.reference.com/browse/comic strip >. Acesso em: 13 de janeiro de 2015.

CRISTOVAO, V. L. L. Modelos didáticos de gênero: uma abordagem para o ensino de língua estrangeira. Londrina: UEL, 2007 
CRISTOVÃO,V.L.L. Para uma expansão do conceito de capacidades de linguagem. IN: BUENO, L.; LOPES, M.A.P.T; CRISTOVÃO, V.L.L. (Org.). Gêneros textuais e formação inicial:homenagem à Malu Matencio. 1. ed. Campinas, SP: Mercado de Letras, 2013. P. $357-383$.

CRISTOVAO, V. L. L. et al. Elaboração de Sequências Didáticas para o Ensino de Língua Estrangeira - uma produção coletiva. 2010. Disponível em: $<$ http://linguagem. unisul.br/paginas/ensino/pos/linguagem/cd/Port/132.pdf $>$. Acesso em: 14 de outubro de 2013.

CRISTOVAO, V.L.L., DURÃO, A.B.A. B., NASCIMENTO, E.L. História em quadrinhos em inglês e em espanhol:um gênero a ser desconstruído e descrito. IN: CRISTOVAO, V.L.L.(ORG) Modelos didáticos de gênero: uma abordagem para o ensino de língua estrangeira . Londrina: UEL, 2007.

CRISTOVÃO, V.L.L.; NASCIMENTO, E.L. Gêneros textuais e ensino: contribuições do interacionismo sociodiscursivo. In: KARWOSKI,A.M.; GAYDECZKA, B.; BRITO, K.S.(Org.) Gêneros textuais:reflexões e ensino. 4.ed.São Paulo: Parábola Editorial, 2011. p.33-52

CRISTOVÃO, V. L. L.; STUTZ, L. Sequências didáticas:semelhanças e especificidades no contexto francófono como L1 no contexto brasileiro como LE. In: SZUNDY, Paula Tatianne Carréra et al (Orgs.). Linguística Aplicada e Sociedade. Ensino e Aprendizagem de Línguas no Contexto Brasileiro. Campinas, SP.Pontes Editores, 2011.

DOLZ, J.; NOVERRAZ,M.; SCHNEUWLY, B. Sequências didáticas para o oral e a escrita:apresentação de um procedimento. In: SCHNEUWLY, B.; DOLZ,J.et.al. Gêneros orais e escritos na escola.Campinas: Mercado de Letras, Ed.2, 2010.

HOFFMANN, A.E.; COSTA, M.U. Gêneros textuais:proposta de ensino a partir de HQs. Revista Língua \& LiteraturaFWv. 11n. 17p. 29-52 Dez. 2009.

KELLY, D.Difference between comic books and graphic novels.2014. Disponível em: $<$ http://knowledgenuts.com/2014/01/07/difference-between-comic-books-and-graphicnovels/>. Acesso em: 12 de janeiro de 2015.

LEAL, A.A. A organização textual do gênero cartoon: aspectos lingüísticos e condicionamentos não linguísticos. Tese (Doutorado em Linguística - Teoria do Texto) - Faculdade de Ciências Sociais e Humanas - Universidade Nova de Lisboa. Portugal. 2011. 
LENHARO, R. I. Participação social por meio da música e da aprendizagem de língua inglesa em um contexto de vulnerabilidade social. 2016. 148 f. Dissertação (Mestrado em Estudos da Linguagem) - Universidade Estadual de Londrina, Londrina, 2016.

MACHADO, A. R.; CRISTOVÃO, V. L. L.. A construção de modelos didáticos de gêneros: aportes e questionamentos para o ensino de gêneros. Linguagem em (Dis)curso - LemD, Tubarão, v. 6, n. 3, p. 547-573, set./dez. 2006. Disponível em: <http://linguagem. unisul.br/paginas/ensino/pos/linguagem/linguagem-em-discurso/0603/060309.pdf>. Acesso em: 15 de outubro de 2014.

MARCUSCHI, L.A.Gêneros textuais:definição e funcionalidade. IN: DIONÍSIO, A.P.; MACHADO, A.R.; BEZERRA,M.A (Org.). Gêneros texuais \& Ensino, São Paulo: Parábola Editorial, 2010.

MATTAR, Marileize França. A Construção do processo de leitura do gênero tiras em quadrinhos em língua inglesa no $7^{\circ}$ ano do ensino fundamental.Dissertação (Mestrado em Linguagem e Identidade) - Universidade Federal do Acre. Rio Branco: UFAC, 2010.189f. Disponível em: <http:/www.letras.ufmg.br/profs/reinildes/dados/arquivos/ marileizemattar.pdf $>$. Acesso em: 13 de junho de 2014.

McCLOUD, S. Understanding comics:the invisible art. New York, Harper Collins Publishers, Inc., 1993. Disponível em: <http://www.uic.edu.hk/ amyzhang/teaching/ COMP3050/readings/McCloud_Understanding_Comics.pdf $>$ Acesso em 10 de junho de 2014.

MENDONÇA, M. R. de S..Um gênero quadro a quadro: a história em quadrinhos. In: DIONÍSIO, A.P.; MACHADO, A.R.; BEZERRA, M.A.(ORG). Gêneros textuais e ensino. 1.ed. São Paulo: Parábola Editorial, 2010.p.209-224

MOTTA, Sérgio Roberto da.Compreensão escrita de história em quadrinhos em língua estrangeira. Dissertação (Mestrado em Lingüística Aplicada e Estudos da Linguagem) - Pontifícia Universidade Católica de São Paulo - PUC. São Paulo, 2009. Disponível em: $\quad<$ http://www4.pucsp.br/pos/lael/laelinf/teses/ex.\%20rosinda_ramos_\%20ME_09_ LAEL_\%20pdf.pdf $>$. Acesso em:7 de junho de 2014.

NASCIMENTO, E.L.. Práticas de letramento, gênero e interação social: o saber e o fazer dos professores do ensino fundamental. In: COLÓQUIO INTERNACIONAL DE ESTUDOS LINGUÍSTICOS ELITERÁRIOS - CIELLI, 1., 2010, Maringá. Anais... Maringá: UEM/ PLE, 2010. Disponível em: $<$ http://anais.cielli.com.br/artigos $>$. Acesso em: 12 fevereiro. 2015. 
NICOLAU, M. As tiras e outros gêneros jornalísticos: uma análise comparativa.Ano VI, n. 02 - fevereiro/2010. Disponível em: <http://www.insite.pro.br/2010/fevereiro/ tirinhas_genero_jornalistico_nicolau.pdf $>$ Acesso em: 2 de julho de 2014.

PINTO, V.M.R. Intertextualidade intergêneros e heterogeneidade tipológica na argumentação publicitária.Dissertação (Mestrado em Estudos da Linguagem) Universidade Estadual de Londrina. Londrina, PR, 2011.

PRESSER, A.T.de R.; SCHLÖL, L. Histórias em quadrinhos enquanto meio de comunicação eficaz.Razón y Palabra. N. 83, jun-ago, 2013. Disponível em: <http://www. razonypalabra.org.mx/N/N83/V83/22_TeixeiraSchlog1_V83.pdf $>$ Acesso em: 20 de jun., 2014.

STUTZ, L. Sequências didáticas, socialização de diários e autoconfrrontação: instrumentos para a formação inicial de professores de inglês. Tese (Doutorado em Estudos da Linguagem) - Universidade Estadual de Londrina. Londrina, PR, 2012. Disponível em: <http://www.bibliotecadigital.uel.br/document/?code=vtls000178953> Acesso em: 13 de janeiro de 205.

STUTZ, L.; BIAZI, T.M.D.A. A construção de sequências didáticas com o gênero tiras em quadrinhos no ensino de LI. 2007, Disponível em: <http://linguagem.unisul.br/paginas/ ensino/pos/linguagem/eventos/cd/Port/69.pdf> Acesso em: 13 de jan.,2014.

PESSOA, A.R. As histórias em quadrinhos nas aulas de língua portuguesa como instrumento de leitura e de produção autoral. Tese (Doutorado em Letras) Universidade Presbiteriana Mackenzie, 2010. Disponível em <http://200.130.0.199/vufind/Record/ bdtd-IPM:oai:mx.mackenzie.com.br:1175>. Acesso em: 12 de janeiro de 2015.

PETRINI, P. Gêneros discursivos iconográficos de humor no jornal O Pasquim: uma janela para a liberdade de expressão. Dissertação (Mestrado em Comunicação) Universidade Estadual de Londrina. Londrina, PR, 2012. Disponível em: <http://www. uel.br/pos/mestradocomunicacao/wp-content/uploads/Petrini-FINAL-diagramadaonline.pdf $>$. Acesso em: 20 de janeiro de 2015.

PONTARA, C. L. Gêneros textuais e sequência didática propiciando um ensino significativo de análise linguística e expressão escrita em língua inglesa. 2015. $444 \mathrm{f}$. Dissertação (Mestrado em Estudos da Linguagem) - Universidade Estadual de Londrina, Londrina, 2015.

RAMOS, P. Histórias em quadrinhos: gênero ou hipergênero? Estudos Linguísticos, São Paulo, 38 (3): 355-367, set.-dez. 2009. Disponível em: <http://gel.locaweb.com.br/ estudoslinguisticos/volumes/38/EL_V38N3_28.pdf $>$ Acesso em:15 de jan., 2014. 
SANTOS, R.E. Leitura semiológica dos Quadrinhos. Revista IMES. Janeiro a Junho, 2002. Disponível em: < http://seer.uscs.edu.br/index.php/revista_comunicacao_inovacao/ article/viewFile/86/642>. Acesso em: 25 de junho de 2014.

SCHNEUWLY, B; DOLZ, J. et al. Gêneros orais e escritos na escola. Campinas: Mercado das Letras. Ed.2, 2010.

VIEIRA, L.J.M.; CAVEDON, N.R.Uma pesquisa que não está no gibi:um estudo com colecionadores de revistas em quadrinhos. Gestão.Org. - Recife. Vol.11, n ${ }^{\circ} 1$, p.1-33, Jan./Abr. 2013. Disponível em: <http://www.revista.ufpe.br/gestaoorg/index.php/gestao> Acesso em: 15 de jun., 2014.

WHAT IS A POLITICAL CARTOON? Wisegeek. [S.1.: s.n., 19--]. Disponível em: $<$ http://www.wisegeek.com/what-is-a-political-cartoon.htm > Acesso em: 8 de janeiro de 2015. 